\title{
Concentration of progesterone during the development of the ovulatory follicle: II. Ovarian and uterine responses
}

\author{
R. L. A. Cerri,, R. C. Chebel,† F. Rivera,‡ C. D. Narciso,‡ R. A. Oliveira,‡ M. Amstalden,§ \\ G. M. Baez-Sandoval,§ L. J. Oliveira, $\neq$ W. W. Thatcher, $\ddagger$ and J. E. P. Santos $\ddagger^{1}$ \\ *Faculty of Land and Food Systems, University of British Columbia, Vancouver, BC V6T 1Z4, Canada \\ †Department of Veterinary Population Medicine, University of Minnesota, St. Paul 55108 \\ $\ddagger$ Department of Animal Sciences, University of Florida, Gainesville 32611 \\ §Department of Animal Science, Texas A\&M University, College Station 77843
}

\begin{abstract}
Two experiments evaluated the influence of altering the concentrations of progesterone during the development of the ovulatory follicle on the composition of the follicular fluid, circulating $\mathrm{LH}$ and $\mathrm{PGF}_{2 \alpha}$ metabolite (PGFM), and expression of endometrial progesterone receptor and estrogen receptor- $\alpha$. In both experiments, the estrous cycles were presynchronized $(\mathrm{GnRH}$ and progesterone insert followed by insert removal and $\mathrm{PGF}_{2 \alpha} 7 \mathrm{~d}$ later, and $\mathrm{GnRH}$ after $48 \mathrm{~h}$ ) and cows were then enrolled in 1 of 2 treatments $7 \mathrm{~d}$ later (study $\mathrm{d}$ -16): high progesterone (HP) or low progesterone (LP). In experiment $1(\mathrm{n}=19)$, cows had their estrous cycle synchronized starting on study d -9 (GnRH and progesterone insert on $\mathrm{d}-9$, and insert removal and $\mathrm{PGF}_{2 \alpha}$ on $\left.\mathrm{d}-2\right)$. In experiment $2(\mathrm{n}=25)$, cows were submitted to the same synchronization protocol as in experiment 1, but had ovulation induced with $\mathrm{GnRH}$ on study d 0 . In experiment 1 , plasma was sampled on $\mathrm{d}-4$ and analyzed for concentrations of $\mathrm{LH}$; the dominant follicle was aspirated on $\mathrm{d} 0$ and the fluid analyzed for concentrations of progesterone, estradiol, and free and total IGF-1. In experiment 2, follicular development and concentrations of progesterone and estradiol in plasma were evaluated until study d 16 . Uterine biopsies were collected on d 12 and 16 for progesterone receptor and estrogen receptor- $\alpha$ protein abundance. An estradiol/oxytocin challenge for PGFM measurements in plasma was performed on d 16. In experiments 1 and 2, LP cows had lower plasma concentrations of progesterone and greater concentrations of estradiol, and had larger ovulatory follicle diameter (20.4 vs. $17.2 \mathrm{~mm}$ ) at the end of the synchronization protocol than HP cows. Concentration of LH tended to be greater for LP than HP cows (0.98 vs. $0.84 \mathrm{ng} /$ $\mathrm{mL}$ ). The dominant follicle of LP cows had greater
\end{abstract}

Received August 17, 2010.

Accepted March 7, 2011.

${ }^{1}$ Corresponding author: jepsantos@ufl.edu concentration of estradiol ( 387.5 vs. $330.9 \mathrm{ng} / \mathrm{mL}$ ) and a lower concentration of total IGF-1 (40.9 vs. $51.7 \mathrm{ng} /$ $\mathrm{mL}$ ) than that of HP cows. In experiment 2, estradiol and progesterone concentrations did not differ between treatments from d 0 to 16; however, the proportion of cows with a short luteal phase tended to increase in LP than HP (25 vs. 0\%). Concentrations of PGFM were greater for LP than HP. Uterine biopsies had a greater abundance of progesterone receptor, and tended to have less estrogen receptor- $\alpha$ abundance on d 12 compared with d 16. An interaction between treatment and day of collection was detected for estrogen receptor- $\alpha$ because of an earlier increase in protein abundance on d 12. Reduced concentrations of progesterone during the development of the ovulatory follicle altered follicular dynamics and follicular fluid composition, increased basal LH concentrations, and prematurely increased estrogen receptor- $\alpha$ abundance and exacerbated $\mathrm{PGF}_{2 \alpha}$ release in the subsequent estrous cycle.

Key words: dairy cow, follicle, luteolysis, progesterone

\section{INTRODUCTION}

Lactating dairy cows normally have lower concentrations of circulating progesterone and estradiol during the estrous cycle than nonlactating cows and growing heifers (Sangsritavong et al., 2002; Sartori et al., 2004), which is partly caused by their increased hepatic blood flow and steroid clearance (Sangsritavong et al., 2002; Vasconcelos et al., 2003). The decrease in concentrations of progesterone and estradiol before ovulation are associated with changes in the pattern of follicular wave development (Wiltbank et al., 2006), and could cause a premature increase in secretion of $\mathrm{PGF}_{2 \alpha}$ following ovulation (Shaham-Albalancy et al., 2001). Increased concentrations of progesterone before and after AI are often positively associated with fertility (Inskeep and Dailey, 2005), but the mechanisms are not clearly understood.

Progesterone has a significant effect on follicle development by regulating LH pulse frequency and estradiol 
synthesis (Savio et al., 1993), which can affect length of dominance of the ovulatory follicle and oocyte and embryo quality (Ahmad et al., 1995; Revah and Butler, 1996; Cerri et al., 2009). Theca and granulosa cells are the main sites of steroid synthesis, as well as local producers of IGF-1 and IGF binding proteins (IGFBP; Echternkamp et al., 1994). Increased free IGF-1 in the follicular fluid influences deviation and development of the dominant follicle (Fortune et al., 2004; Spicer, 2004), which seems to be related to IGFBP-2 in the follicular fluid that is inversely related to estradiol synthesis (Echternkamp et al., 1994; Lucy et al., 1995; Guzeloglu et al., 2001). Increased concentrations of progesterone during follicle development could yield better quality oocytes or affect subsequent corpus luteum (CL) formation by altering the follicular IGF-1 system.

Optimal uterine function for the developing embryo and attenuation of $\mathrm{PGF}_{2 \alpha}$ pulsatile synthesis during the period of maternal recognition of pregnancy are dependent on progesterone. The proper temporal expression of progesterone receptor, estrogen receptor- $\alpha$, and oxytocin receptor in the endometrium are important to regulate $\mathrm{PGF}_{2 \alpha}$ synthesis and luteolysis (Spencer and Bazer, 2004). When cows experience reduced concentrations of progesterone and estradiol before ovulation, short luteal phases caused by premature release of $\mathrm{PGF}_{2 \alpha}$ by the endometrium may occur (Garverick et al., 1992; Zollers et al., 1993). Progesterone and estradiol are the main regulators of progesterone receptor and estrogen receptor- $\alpha$ during the estrous cycle. Therefore, it is reasonable to hypothesize that reduced concentrations of ovarian steroids in plasma, normally observed in high-producing dairy cows, could disrupt the ideal progesterone receptor and estrogen receptor- $\alpha$ profile in the endometrium necessary for a successful pregnancy.

The objectives of the present study were to determine the effect of concentrations of progesterone in plasma during growth of the ovulatory follicle on concentration of LH in plasma, steroidal (i.e., estradiol and progesterone), and IGF-1 (i.e., total and free) composition of the antral fluid of the ovulatory follicle, circulating concentrations of progesterone and estradiol, and ovarian follicle dynamics. In addition, the concentration of PGF $_{2 \alpha}$ metabolite (PGFM) in plasma, as well as progesterone receptor and estrogen receptor- $\alpha$ protein abundance in the endometrium during the estrous cycle subsequent to the treatments were measured. A suboptimal concentration of progesterone before ovulation could alter oocyte maturation and the subsequent temporal programming of the uterus before the time of CL maintenance, with possible negative effects on fertility.

\section{MATERIALS AND METHODS}

\section{Animals, Housing, and Diets}

The University of California-Davis Institutional Animal Care and Use Committee approved all procedures in this study. Forty-four (18 primiparous and 26 multiparous) lactating Holstein cows from one dairy located in the San Joaquin Valley of California were enrolled in the current study and divided between experiment $1(\mathrm{n}=19)$ and experiment $2(\mathrm{n}=25)$. The average number of lactating cows in the herd during the study was 900, and the 305-d 3.5\% FCM rolling herd average was $11,590 \mathrm{~kg} / \mathrm{cow}$ per year. Animals were housed in freestall barns equipped with fans and sprinklers that were automatically turned on when temperature reached $26.7^{\circ} \mathrm{C}$. All cows were fed the same diet as a TMR twice daily to meet or exceed the dietary requirements for lactating cows weighing $680 \mathrm{~kg}$, consuming 24 $\mathrm{kg}$ of DM, and producing $45 \mathrm{~kg}$ of milk containing $3.5 \%$ fat and $3.1 \%$ true protein in the first 70 DIM (NRC, 2001).

All cows had their BCS evaluated at $33 \pm 3$ and $65 \pm$ 3 DIM according to Ferguson et al. (1994). Only cows with $\mathrm{BCS} \geq 2.25$ at $33 \pm 3$ DIM were enrolled in the study. Cows were classified according to the average BCS at $33 \pm 3$ and $65 \pm 3$ DIM as having low BCS if the average $\mathrm{BCS} \leq 2.75$ or moderate $\mathrm{BCS}$ if the average BCS $>2.75$. Cows diagnosed with any evident health disorder (displacement of the abomasum, lameness, pyometra, and uterine adhesions) were not enrolled in the study.

\section{Treatments}

Starting at $33 \pm 3$ DIM, all cows in experiment 1 and experiment 2 had their estrous cycles presynchronized with an injection of GnRH (100 $\mu \mathrm{g}$ of gonadorelin diacetate tetrahydrate; $2 \mathrm{~mL}$ of Cystorelin, Merial Ltd., Iselin, NJ) and a controlled internal drug-release insert (CIDR; Eazi-Breed CIDR, Pfizer Animal Health, New York, NY) containing $1.38 \mathrm{~g}$ of progesterone. Seven days later cows received an injection of $\mathrm{PGF}_{2 \alpha}(25 \mathrm{mg}$ of dinoprost tromethamine; $5 \mathrm{~mL}$ of Lutalyse, Pfizer Animal Health) concurrent with the removal of the CIDR insert, and $48 \mathrm{~h}$ later all cows received a second injection of GnRH (study d -16). On study d -16 , cows were allocated randomly to 1 of 2 treatments: high progesterone (HP) or low progesterone (LP). In both treatments, all cows were synchronized as follows: GnRH injection and CIDR insert on study d -9 , and CIDR removal and injection of $\mathrm{PGF}_{2 \alpha}$ on study $\mathrm{d}-2$. Only cows in experiment 2 received a final injection 

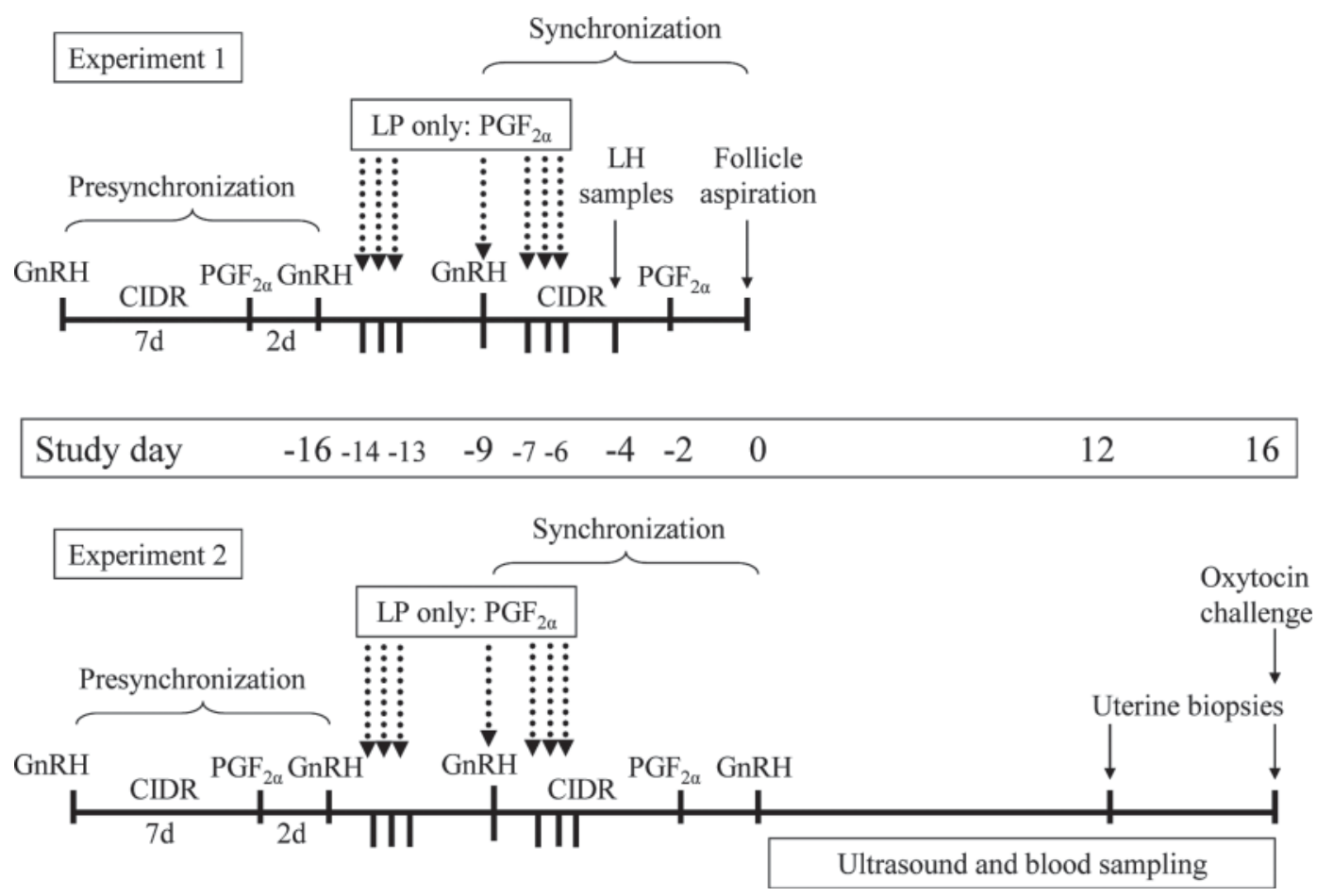

Figure 1. Diagram of the synchronization protocols and activities performed in experiment 1 and experiment 2 . CIDR $=$ controlled internal drug-release containing $1.38 \mathrm{~g}$ of progesterone; $\mathrm{LP}=$ low progesterone treatment.

of GnRH on study d 0 to induce ovulation (Figure 1). Cows in HP received no further treatment, whereas LP cows received additional $\mathrm{PGF}_{2 \alpha}$ injections on study $\mathrm{d}$ $-14,-13.5$, and -13 , and again on study d $-9,-7$, -6.5 , and -6 (Figure 1). This approach was based on work by Beal et al. (1980).

\section{Experiment 1}

There were 9 cows in the HP and 10 cows in the LP treatments in experiment 1 .

Blood Samples and Analyses of Progesterone and Estradiol. Approximately $7 \mathrm{~mL}$ of blood was collected by puncture of the median coccygeal vein or artery utilizing Vacutainer tubes (Becton Dickinson Vacutainer Systems, Rutherford, NJ) with $\mathrm{K}_{2}$ EDTA. Blood samples were collected before CIDR insertion when the 2 activities coincided. Samples were placed immediately in ice, transported to the laboratory within $5 \mathrm{~h}$, and centrifuged at 2,000 $\times g$ for $15 \mathrm{~min}$ for separation of plasma. Plasma samples were frozen at $-25^{\circ} \mathrm{C}$ and later analyzed for concentrations of progesterone and estradiol.

Blood samples for analysis of concentration of progesterone were collected on study d $-16,-14,-11$, $-9,-7,-4,-2$, and 0 . Plasma samples were analyzed in duplicate for concentration of progesterone by an
ELISA validated by Cerri et al. (2004). Each microplate contained the standards $(0.1,0.2,0.5,1.0,2.0$, $5.0,10.0$, and $20.0 \mathrm{ng} / \mathrm{mL}$ ), and the intra- and interassay CV were 5.6 and $10.1 \%$, respectively. Cows with concentrations of progesterone in plasma $\geq 1.0 \mathrm{ng} / \mathrm{mL}$ immediately before the $\mathrm{PGF}_{2 \alpha}$ injection of the synchronization protocol and then $<1.0 \mathrm{ng} / \mathrm{mL} 48 \mathrm{~h}$ later were described as having undergone luteolysis. Estradiol concentration was measured using a validated RIA procedure (Kirby et al. 1997). Standards for this assay were $0.25,0.50,1.0,2.5,5.0,7.5,10.0$, and $20.0 \mathrm{pg} / \mathrm{mL}$, and the intra- and interassay CV were 9.3 and $11.9 \%$, respectively.

Blood Samples and Analysis of LH. Approximately $7 \mathrm{~mL}$ of blood was collected by puncture of the median coccygeal vein or artery utilizing Vacutainer tubes (Becton Dickinson Vacutainer Systems) without anticoagulant for serum separation for determination of concentrations of $\mathrm{LH}$ at 15-min intervals for $3 \mathrm{~h}$ on study $\mathrm{d}-4$. Concentrations of $\mathrm{LH}$ in serum were determined by RIA as previously reported (McVey and Williams, 1991) using a highly purified ovine LH [AFP-8614B, NIDDK-oLH-I-4; National Hormone and Pituitary Program (NHPP), Harbor-UCLA Medical Center, Torrance, CA] as both the reference preparation and as iodinated tracer. The primary antiserum used was produced in rabbits immunized against ovine 
LH (AFP-192279, NIDK-anti-oLH-1; NHPP). This antiserum shows similar cross-reactivity between highly purified preparations of ovine (NIDDK - I-2) and bovine (AFP11743B) LH and does not cross-react with other pituitary hormones. Sensitivity of the assay was $0.1 \mathrm{ng} / \mathrm{mL}$ and the intra- and interassay CV averaged 9.3 and $10.0 \%$, respectively.

Ovarian Ultrasonography. Cows had their ovaries examined by ultrasound (Sonovet 2000, Universal Medical System, Bedford Hills, NY) using a 7.5-MHz linear rectal transducer. The first 2 ovarian examinations (33 \pm 3 and $40 \pm 3 \mathrm{DIM})$ of the ovaries were intended to detect the presence of a CL to determine the cyclic status (cyclic vs. anovular) before initiation of the treatments. A cow was considered cyclic if a CL was observed in at least 1 of the 2 ultrasound examinations, and classified as anovular if no CL was detected in either of the 2 examinations. Ultrasound examinations of the ovaries were then performed at every injection of the synchronization protocol and $48 \mathrm{~h}$ after each $\mathrm{GnRH}$ injection. Maps of the ovaries were drawn for each individual cow, and size and position of follicles $\geq 5 \mathrm{~mm}$ in diameter and CL were recorded. Occurrence of ovulation within $48 \mathrm{~h}$ after each $\mathrm{GnRH}$ injection was characterized by the absence of a previously recorded follicle $\geq 10 \mathrm{~mm}$ in diameter and confirmed by the appearance of a CL $7 \mathrm{~d}$ later.

Follicular Fluid Collection and Hormonal Analyses. The follicular fluid of the dominant follicle was aspirated $48 \mathrm{~h}$ after the last $\mathrm{PGF}_{2 \alpha}$ injection of the synchronization protocol (study d 0). A 5.0-MHz convex-array transducer (Aloka SSD-500, Aloka Co. Ltd., Wallingford, CT) was used to guide the transvaginal placement of the aspiration needle. The 17-gauge single lumen needle and the transducer were both mounted in a plastic handle and carefully introduced into the vaginal fornix after the cow received an epidural anesthesia with $4 \mathrm{~mL}$ of $2 \%$ lidocaine (Lidocaine $\mathrm{HCl} 2 \%$, RXV Products, Roanoke, TX). The dominant follicle targeted for aspiration was then localized on the display of the ultrasound machine, and the needle inserted carefully into the follicle, with placement confirmed by the appearance of the echogenic tip of the needle inside the follicle. The follicular fluid was then slowly aspirated using a $10-\mathrm{mL}$ syringe attached to the needle until the follicle completely disappeared on the display. Following collection, the follicular fluid was immediately placed in ice and later preserved at $-25^{\circ} \mathrm{C}$ until analysis. The follicular fluid was analyzed for concentrations of estradiol, progesterone, and free and total IGF-1. Estradiol was analyzed by RIA using a modified protocol described by Kirby et al. (1997). Progesterone was analyzed by ELISA validated by Cerri et al. (2004) using a 1:10 dilution for the samples of follicular fluid.
The free and total IGF-1 analyses of the follicular fluid were performed using a commercial ELISA kit (DSL109400 Free IGF-1 and DSL10-2800 nonextraction IGF-1, Diagnostic Systems Laboratories Inc., Webster, TX) according to manufacturer's instructions.

\section{Experiment 2}

There were 13 cows in the HP and 12 cows in the LP treatments in experiment 2 .

Blood Sampling and Analyses of Progesterone and Estradiol. Blood was sampled and plasma separated exactly as in experiment 1 . The schedule of blood sampling was identical to that of experiment 1 until study d 0. Additional blood samples were also collected on study d $3,5,7,10,12,14$, and 16 in the subsequent estrous cycle after the end of the synchronization protocol. The intra- and interassay $\mathrm{CV}$ for the progesterone assays were 5.4 and $11.1 \%$, respectively. The intra- and interassay CV for estradiol were 9.9 and $12.5 \%$, respectively. Cows with a short luteal phase were removed from the analysis of progesterone concentrations during the estrous cycle subsequent to induction of ovulation in the synchronization program.

Ovarian Ultrasonography. Ultrasound examinations of the ovaries were performed exactly as in experiment 1 following the same schedule until study $d$ 16. Additional ultrasound examinations of the ovaries were performed on study d $3,5,7,10,12,14$, and 16 to follow the growth of the dominant follicle and CL in the estrous cycle subsequent to the synchronization protocol. Short luteal phase in the cycle subsequent to the synchronization protocol was characterized by the decline in concentrations of progesterone in plasma $<1$ $\mathrm{ng} / \mathrm{mL}$ before study d 10 .

Oxytocin Challenge and Analysis of 13, 14-Dihydro-15-keto-PGF $\boldsymbol{F}_{2 \alpha}$. The oxytocin challenge was initiated on study d 16 by treating cows with an i.m. injection of estradiol cypionate $(1 \mathrm{mg}$; Pfizer Animal Health) $4 \mathrm{~h}$ before intravenous administration of oxytocin (100 IU; Phoenix Pharmaceuticals, St. Joseph, MO) as described previously by Mattos et al. (2002). Cows that underwent a short luteal phase were removed from the challenge. Blood samples were collected at $-15,0,15,30,45,60,90,120$, and 180 min relative to the injection of oxytocin and collection only started after the uterine biopsy procedure. Plasma samples were analyzed for concentrations of PGFM by RIA as described by Guilbault et al. (1984).

Procedures for blood collection, plasma separation, and storage were the same as described in experiment 1.

Uterine Biopsies and Immunohistochemistry for Progesterone Receptor and Estrogen 
Receptor- $\alpha$. Uterine biopsies were performed on study d 12 and 16. Biopsy on study d 16 was performed before the oxytocin challenge. Cows in each group received an epidural anesthesia with $4 \mathrm{~mL}$ of $2 \%$ lidocaine (Lidocaine $\mathrm{HCl} 2 \%$, RXV Products) before the procedure. The uterine biopsy instrument was inserted through the cervix until it reached a position adjacent to the external intercornual ligament. Endometrial tissue was collected from the uterine horn ipsilateral to the CL, immediately removed from the instrument, and placed for $24 \mathrm{~h}$ in a solution of $4 \%$ paraformaldehyde in a 9:1 (vol/vol) proportion for prefixation. The tissue was then dehydrated using serial alcohol solutions, and then embedded in paraffin until analyzed for progesterone receptor and estrogen receptor- $\alpha$.

The biopsy samples of endometrium for quantification of progesterone receptor and estrogen receptor- $\alpha$ were processed by preparing $4-\mu \mathrm{m}$ sections with a microtome. The sections were placed in poly-L-lysinecoated glass slides, and had the paraffin removed and were rehydrated using a xylene substitute (Safeclear, Fisher Scientific, Pittsburgh, PA), serial alcohol solutions, and PBS (0.01 $M \mathrm{Na}_{2} \mathrm{PO}_{4}, 0.85 \%$ wt/vol $\left.\mathrm{NaCl}\right)$. Sections were incubated in citrate buffer $(0.02 M$ citric acid, $0.02 \mathrm{M}$ sodium citrate) for $30 \mathrm{~min}$ at $120^{\circ} \mathrm{C}$ for antigen retrieval and then rinsed 3 times for $5 \mathrm{~min}$ with PBS. The endogenous peroxidase blocking was completed by incubating sections for $30 \mathrm{~min}$ in a $0.3 \%$ $\mathrm{H}_{2} \mathrm{O}_{2}$ solution in PBS, and sections were rinsed 3 times for 5 min with PBS when blocking was finished. The section slides were then circled with a hydrophobic marker (Dako Pen, Dako, Carpinteria, CA), and the remaining procedures for immunohistochemistry were performed using a commercial kit (Vectastain ABC reagent with diaminobenzidine substrate, Vector Laboratories, Burlingame, CA) according to the manufacturer's instructions. Primary antibodies were incubated with PBS solution with $0.1 \%$ azide and $0.1 \%$ BSA. The progesterone receptor antibody was a mouse antihuman nuclear progesterone receptor, isoforms $\mathrm{A}$ and B $(4 \mu \mathrm{g} / \mathrm{mL}$, clone hPRa2+hPRa3, Thermo Scientific, Waltham, MA), and the estrogen receptor- $\alpha$ antibody was a mouse anti-human estrogen receptor- $\alpha$ (1:50 dilution, clone ER1D5, Beckman Coulter, Brea, CA). The negative controls were incubated with mouse IgG (Sigma-Aldrich, St. Louis, MO).

The slides were examined for staining using light microscopy. The expression of progesterone receptor and estrogen receptor- $\alpha$ in endometrial sections were estimated based on a 0 (no positive staining) to 5 (very intense staining) scale. Evaluation was performed blindly with respect to treatment.

\section{Experimental Design and Statistical Analyses}

The experiments were randomized designs with blocks. Within experiment, lactating Holstein cows were blocked at $33 \pm 3$ DIM according to parity (primiparous and multiparous) and BCS (low and moderate) and, within each block, randomly assigned to 1 of the 2 treatments.

Dichotomous outcomes were evaluated by logistic regression using the LOGISTIC procedure of SAS software version 9.2 (SAS Institute Inc., Cary, NC). The model used included the effects of treatment, parity, cyclic status, BCS, and interactions. For incidence of short luteal phase, Fisher's exact test was used.

The immunohistochemical readings for progesterone receptor and estrogen receptor- $\alpha$ expression were analyzed by the GLIMMIX procedure of SAS using a Poisson distribution. The model used included the effects of treatment, parity, day of collection, BCS, and interactions between treatment and parity and treatment and day of collection.

Concentrations of progesterone, estradiol, LH, and PGFM, and ovarian follicular and CL development in experiment 2 were analyzed by ANOVA for repeated measures using the MIXED procedure of SAS. Samples collected for PGFM at -15 and 0 min were used as covariates. The covariance structure with the smallest Akaike's information criterion was used for measurements utilized in the MIXED model. The models included the effects of treatment, day of measurement, parity, BCS, and interactions between treatment and day of measurement, and treatment and parity, with cow nested within treatment as the random error.

Treatment differences with $P \leq 0.05$ were considered significant and from $0.05<P \leq 0.10$ were designated as a tendency.

\section{RESULTS}

The mean and median lactation of cows did not differ $(P>0.12)$ between treatments in experiments 1 and 2. For all 44 cows in both experiments, the mean and median numbers of lactations were $2.3 \pm 0.1$ and 2.0, respectively. Similarly, the mean and median BCS on the day of enrollment did not differ between treatments in both experiments; for the 44 cows in both experiments, they were, respectively, $2.96 \pm 0.29$ and 3.00. The proportion of cows classified as cyclic before the initiation of the synchronization protocols was not different among treatments and averaged $77.3 \%$. All cows in the study ovulated to the GnRH injections of the ovulation synchronization protocol. 


\section{Ovarian Structures and Responses to the Synchronization Protocol}

Design of experiments regarding treatments and timing of ultrasound measurements of ovarian structures was the same for experiments 1 and 2 and these parameters were analyzed together (Table 1). Diameter of the dominant follicle at the first GnRH injection of the synchronization protocol (study d -9 ) was similar between HP and LP cows and averaged $17.7 \pm 1.0 \mathrm{~mm}$. The number of CL at the time of $\mathrm{PGF}_{2 \alpha}$ injection was lower $(P=0.001)$ for LP cows compared with HP cows. Diameter of the dominant follicle at the time of the $\mathrm{PGF}_{2 \alpha}$ injection of the synchronization protocol was larger $(P=0.001)$ for LP compared with HP cows, and remained larger $(P=0.001) 2 \mathrm{~d}$ later. Proportion of cows with double ovulation in experiment 2 did not differ between treatments.

\section{Experiment 1}

Concentrations of Estradiol and Progesterone in Plasma. Study day and interaction between treatment and study day affected $(P=0.001)$ concentrations of estradiol (Figure 2; panel A). Concentrations of estradiol were similar between treatments from study $\mathrm{d}$ -16 to -7 , but were greater $(P=0.001)$ for $\mathrm{LP}$ cows on study $\mathrm{d}-4$ to $0(P=0.001)$ compared with HP cows.

A study day effect and an interaction between treatment and study day $(P=0.001)$ were observed, which reflected the lower $(P<0.05)$ concentration of progesterone for LP than HP cows between study d -9 and -2 (Figure 2; panel B). The concentrations of progesterone at the other collection times were similar between treatments.
Concentrations of LH in Plasma and Composition of Follicular Fluid. Concentration of LH in plasma tended $(P=0.10)$ to be greater for LP $(0.93$ $\mathrm{ng} / \mathrm{mL}$ ) than HP (0.79 ng/mL) cows (Figure 3). No effect of time was observed, but an interaction between treatment and time was observed $(P<0.05)$ at 105 and 150 min after the initiation of blood collection on study d -4 . No difference was observed in the remaining blood sample collections.

No cow displayed estrus when follicles were aspirated $48 \mathrm{~h}$ after $\mathrm{PGF}_{2 \alpha}$. Concentrations of estradiol in the follicular fluid were greater $(P=0.001)$ for LP cows compared with HP cows (Table 2). The concentration of progesterone within the follicular fluid was similar between treatments and averaged $68.0 \pm 9.9 \mathrm{ng} / \mathrm{mL}$. The concentration of free IGF-1 was not different between treatments, but concentration of total IGF-1 was lower $(P=0.02)$ for LP cows compared with HP.

\section{Experiment 2}

Concentrations of Estradiol and Progesterone in Plasma. Study day and an interaction between treatment and study day affected $(P=0.001)$ concentrations of estradiol. Concentrations of estradiol (Figure 4; panel A) were similar between treatments from study $\mathrm{d}-16$ to -7 , but were greater $(P=0.001)$ for LP cows from study d -4 to 0 compared with HP cows. Concentrations of estradiol in the estrous cycle following the synchronization protocol, from study d 3 to 16 , were similar between treatments.

Progesterone concentration was affected by study day $(P=0.001)$, and a treatment by study day interaction $(P=0.001)$ was detected. Progesterone concentration was lower $(P<0.01)$ for LP compared with HP from

Table 1. Effect of treatment on ovarian structures and responses to the synchronization protocol (study $\mathrm{d}-9$ to 0 ; experiments 1 and 2), and proportion of double ovulation following the last injection of $\mathrm{GnRH}$ of the synchronization protocol (study d 0) and short luteal phases in the estrous cycle subsequent to the synchronization protocol (experiment 2)

\begin{tabular}{|c|c|c|c|c|c|}
\hline \multirow[b]{2}{*}{ Item } & \multicolumn{2}{|c|}{ Treatment $^{1}$} & \multirow[b]{2}{*}{$\mathrm{AOR}^{2}$} & \multirow[b]{2}{*}{$95 \%$ CI } & \multirow[b]{2}{*}{$P$-value } \\
\hline & $\mathrm{HP}$ & LP & & & \\
\hline Cows, $\mathrm{n}$ & 22 & 22 & - & - & - \\
\hline $\mathrm{DF}^{3}$ at first $\mathrm{GnRH}, \mathrm{mm}$ & $17.7 \pm 1.0$ & $17.8 \pm 1.1$ & - & - & 0.96 \\
\hline \multicolumn{6}{|l|}{$\mathrm{PGF}_{2 \alpha}$} \\
\hline $\mathrm{DF}, \mathrm{mm}$ & $16.4 \pm 0.6$ & $19.4 \pm 0.7$ & - & - & 0.001 \\
\hline Corpus luteum, $\mathrm{n}$ & $1.8 \pm 0.1$ & $0.6 \pm 0.1$ & - & - & 0.001 \\
\hline \multicolumn{6}{|l|}{ Second GnRH } \\
\hline $\mathrm{DF}, \mathrm{mm}$ & $17.2 \pm 0.4$ & $20.4 \pm 0.4$ & - & - & 0.001 \\
\hline Double ovulation, \% & 7.7 & 25.0 & 0.2 & $0.01-2.5$ & 0.20 \\
\hline Short luteal phase, \% & 0.0 & 25.0 & - & - & 0.09 \\
\hline
\end{tabular}


A)

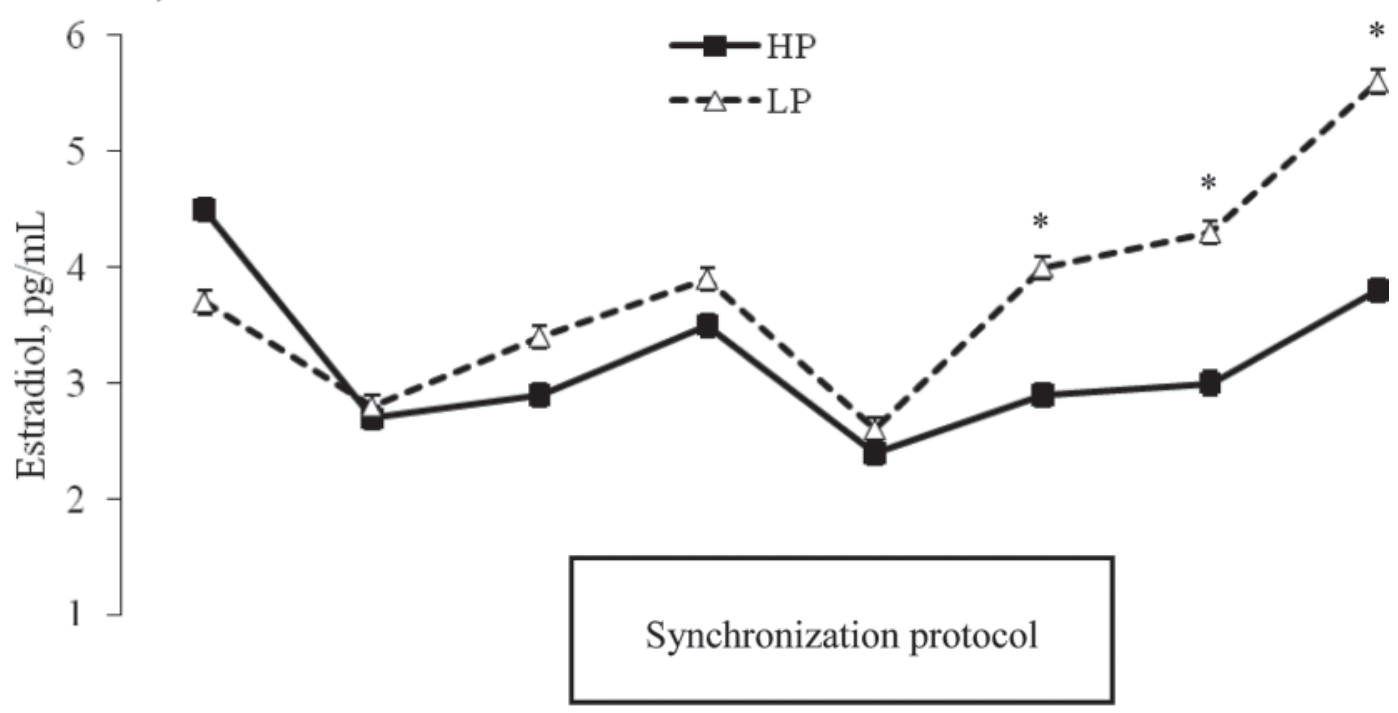

B)

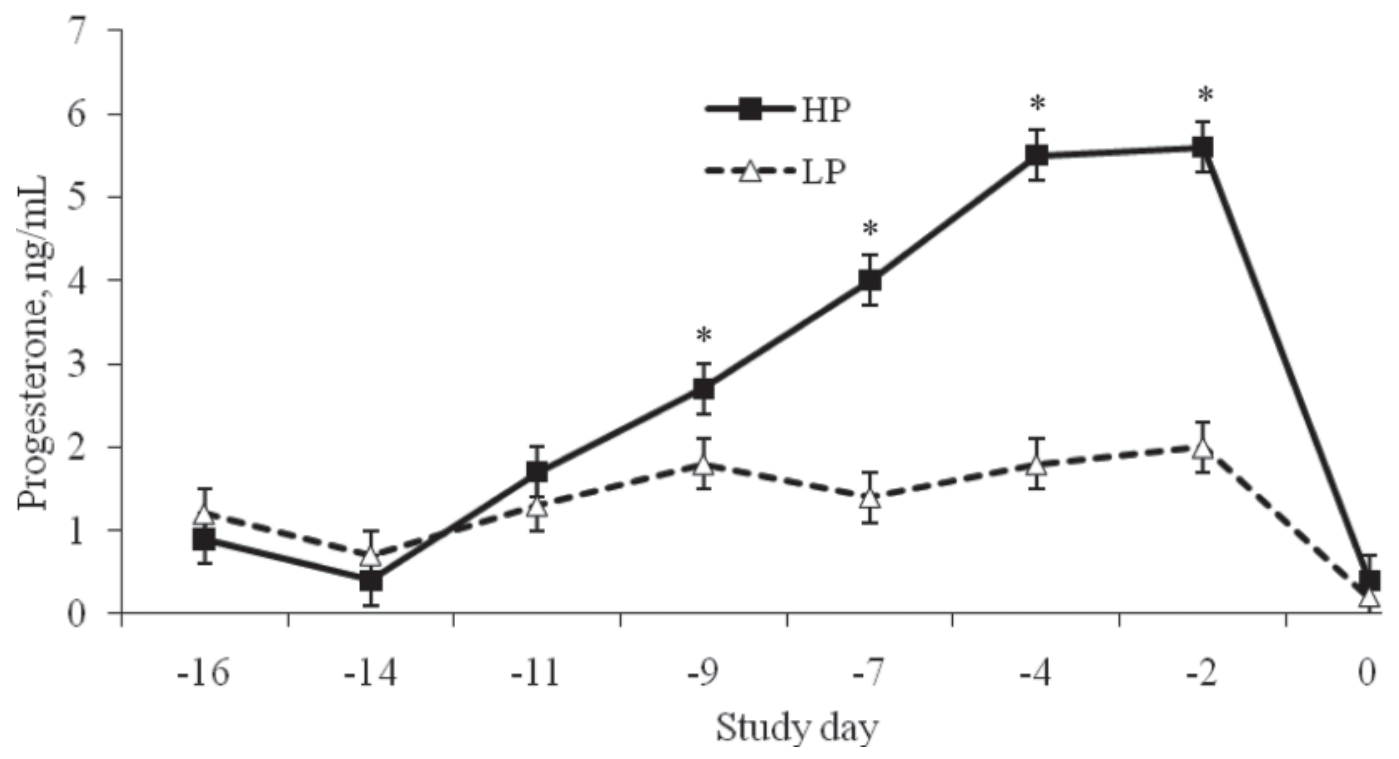

Figure 2. Concentrations of estradiol (panel A) and progesterone (panel B) in plasma of cows in high (HP) and low (LP) progesterone treatments in experiment 1. Effect of treatment $(P<0.04)$, study day $(P<0.001)$, and interaction between treatment and study day $(P=0.001)$ in concentrations of estradiol and progesterone. Within each study day, the asterisk $\left.{ }^{*}\right)$ denotes difference between treatments $(P=0.001)$.

study d -9 to -2 (Figure 4; panel B). During study $\mathrm{d}-16$ to -11 and study $\mathrm{d} 0$ to 16 , concentrations of progesterone were similar between treatments.

Growth of Dominant Follicle and CL During Study $d 0$ and 16. Diameter of the first-wave dominant follicle following the synchronization protocol was similar between treatments (Figure 4; panel C). An effect of study day $(P=0.001)$ was observed, but no interaction between treatment and study day on diameter of the first and second wave dominant follicle was detected. Diameter of the CL (Figure 4; panel D) was affected by study day $(P=0.001)$, and an interaction between treatment and study day was observed $(P=$ 0.05). Diameter of the CL was larger $(P=0.05)$ in LP compared with HP cows on study d $14(30.5 \pm 1.4$ vs. $26.9 \pm 1.2)$ and study d $16(30.3 \pm 1.4$ vs. $27.1 \pm 1.2)$.

Short Luteal Phases and Concentration of PGFM After Oxytocin Challenge. The incidence of short luteal phases (Table 1) tended to be increased $(P=0.09)$ in the LP treatment $(25 \%)$ compared with the HP treatment $(0 \%)$. The concentrations of PGFM in plasma (Figure 5$)$ had an effect of time $(P<0.001)$ and an interaction between treatment and time $(P=$ 0.01). The mean concentration of PGFM was increased 
Table 2. Effect of treatment on the composition of the follicular fluid of the dominant follicle (experiment 1)

\begin{tabular}{lrcc}
\hline & \multicolumn{2}{c}{ Treatment $^{1}$} \\
\cline { 2 - 3 } Item & \multicolumn{1}{c}{ HP } & LP & P-value \\
\hline Estradiol, $\mathrm{ng} / \mathrm{mL}$ & $330.9 \pm 8.9$ & $387.5 \pm 8.9$ & 0.001 \\
Progesterone, $\mathrm{ng} / \mathrm{mL}$ & $65.9 \pm 9.9$ & $69.4 \pm 9.9$ & 0.93 \\
Total IGF-1, ng/mL & $51.7 \pm 3.0$ & $40.9 \pm 3.0$ & 0.02 \\
Free IGF-1, ng/mL & $5.2 \pm 0.8$ & $3.5 \pm 0.8$ & 0.15 \\
\hline
\end{tabular}

${ }^{1} \mathrm{HP}=$ high progesterone; $\mathrm{LP}=$ low progesterone.

$(P<0.05)$ in LP compared with HP cows at $90 \mathrm{~min}$ $(375.5 \pm 67.7$ vs. $123.6 \pm 55.2 \mathrm{pg} / \mathrm{mL})$ and $120 \mathrm{~min}$ $(253.5 \pm 67.7$ vs. $92.5 \pm 55.2 \mathrm{pg} / \mathrm{mL})$ relative to the oxytocin challenge.

Immunohistochemistry for Nuclear Progesterone Receptor $A$ and $B$ and Estrogen Receptor- $\alpha$. The abundance score for the nuclear progesterone receptor A and B in the endometrium (Figure 6, panel A) was greater $(P<0.001)$ on study d 12 than on $d$ $16(2.56 \pm 0.16$ vs. $0.65 \pm 0.16)$. Progesterone receptor abundance score did not differ $(P=0.51)$ between HP and LP treatments in the endometrium sections collected on study d $12(2.31 \pm 0.19$ vs. $2.80 \pm 0.20)$ and study d 16 (0.54 \pm 0.19 vs. $0.75 \pm 0.25)$.

The abundance score for estrogen receptor- $\alpha$ in the endometrium (Figure 6, panel B) tended to be lower $(P=0.10)$ on study d 12 than on d $16(2.69 \pm 0.20$ vs. $3.31 \pm 0.21)$. Estrogen receptor- $\alpha$ expression score was greater $(P=0.05)$ in the LP treatment compared with HP in biopsies collected on study d $12(3.10 \pm 0.33$ vs. $2.29 \pm 0.25)$, but no treatment difference $(P=0.24)$ was observed on study d $16(3.57 \pm 0.25$ vs. $3.06 \pm$ $0.33)$. Pictures of endometrium stained for progester- one receptor and estrogen receptor- $\alpha$ are presented in Figure 7.

\section{DISCUSSION}

Decreasing the concentrations of progesterone during the development of the ovulatory follicle had major effects on follicular dynamics possibly mediated by changes in basal LH concentrations, which resulted in increased concentrations of estradiol, but decreased total IGF-1 in the antral fluid. Moreover, it accelerated the expression of estrogen receptor- $\alpha$ in the endometrium, which induced increased synthesis of $\mathrm{PGF}_{2 \alpha}$ by the endometrium after a challenge with oxytocin and more premature regression of the CL.

The experimental approach was effective in promoting high and low concentrations of progesterone in HP and LP treatments, respectively, which was also validated in similar experimental designs using mid-lactating cows and beef heifers (Shaham-Albalancy et al., 2001; Beltman et al., 2009). The difference in concentrations of progesterone started before the recruitment of the ovulatory follicle and continued until luteolysis was

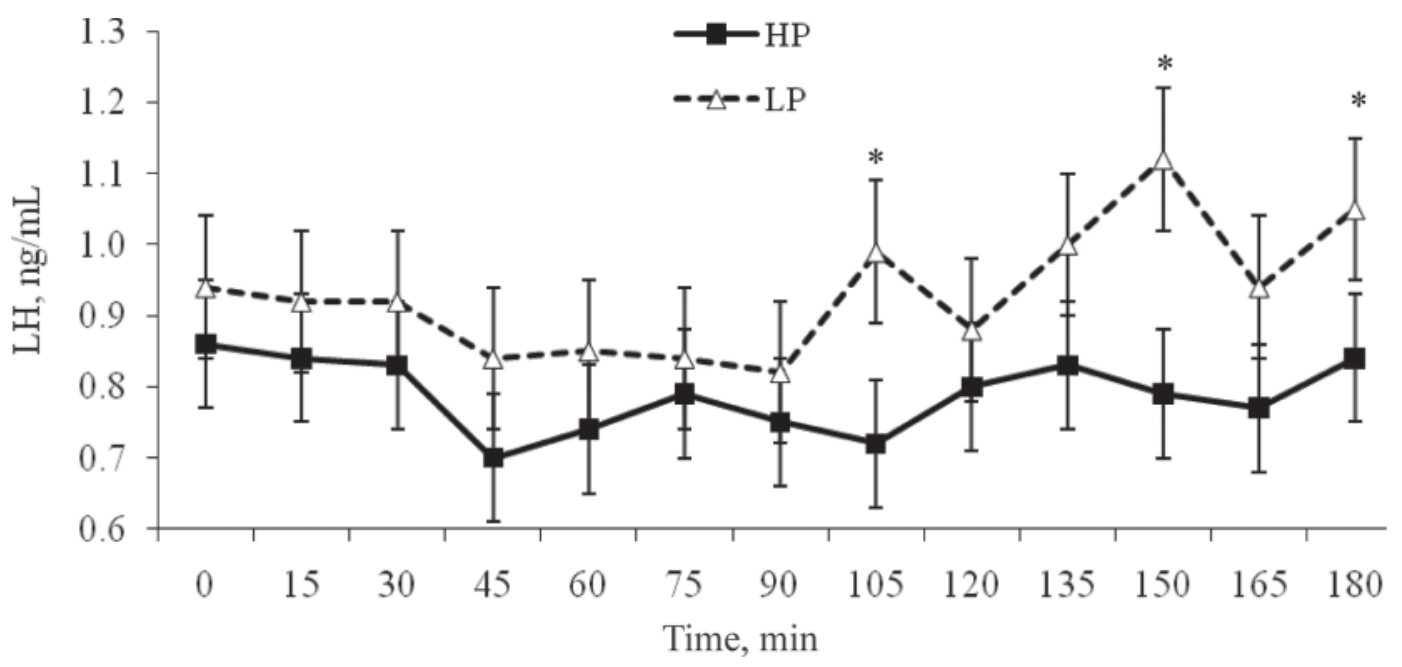

Figure 3. Concentrations of LH in plasma of cows in high (HP) and low (LP) progesterone treatment on study d -4 in experiment 1 . Effect of treatment $(P=0.10)$, time $(P=0.19)$, and interaction between treatment and time $(P<0.05)$. Within each blood collection time, the asterisk $\left.{ }^{*}\right)$ denotes difference between treatments $(P<0.05)$. 

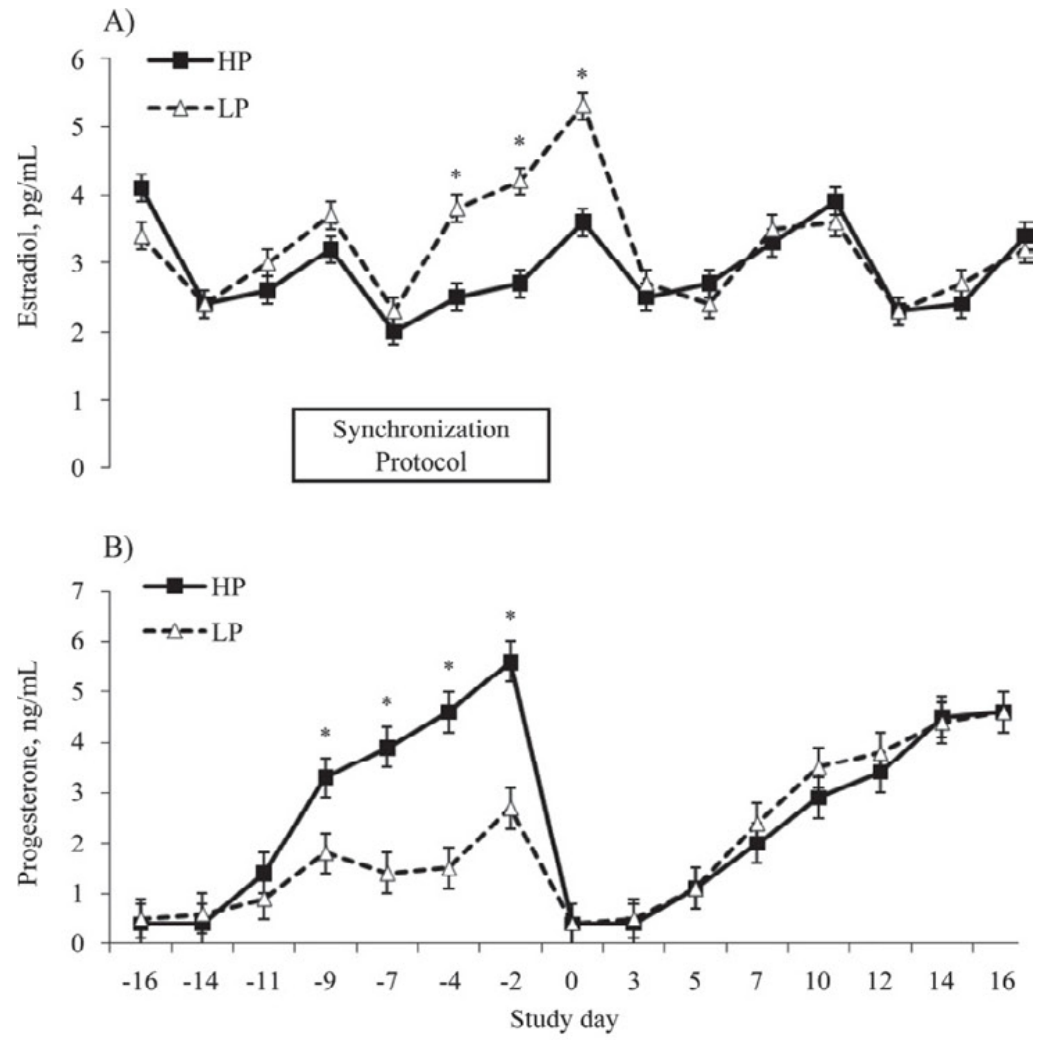

C)

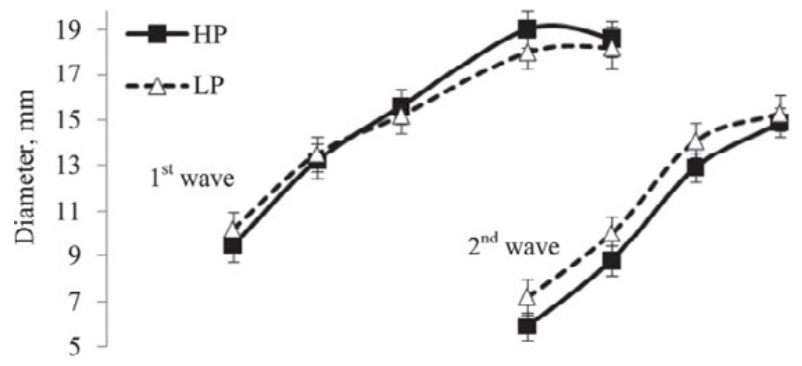

D)

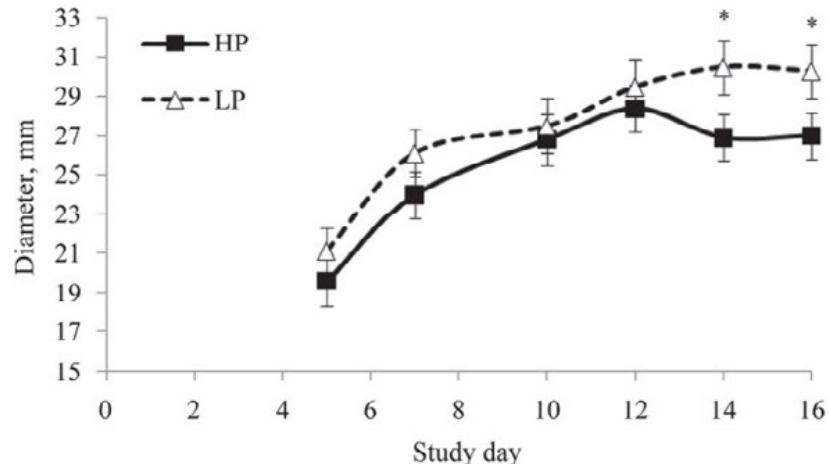

Figure 4. Concentrations of estradiol (panel A) and progesterone (panel B) in plasma, and diameter of the dominant follicle (panel C) and corpus luteum (panel D) of cows in high (HP) and low (LP) progesterone treatments in experiment 2. For concentrations of both estradiol and progesterone, effect of treatment $(P<0.001)$, study day $(P<0.001)$, and interaction between treatment and study day $(P=0.001)$. For dominant follicle growth, effect of treatment $(P<0.75)$, day of estrous cycle $(P=0.001)$, and interaction between treatment and day of estrous cycle $(P<0.83)$. For corpus luteum growth, effect of treatment $(P=0.20)$, day of estrous cycle $(P=0.001)$, and interaction between treatment and day of estrous cycle $(P=0.05)$. Within each study day, the asterisk $\left(^{*}\right)$ denotes difference between treatments $(P=0.001)$. 


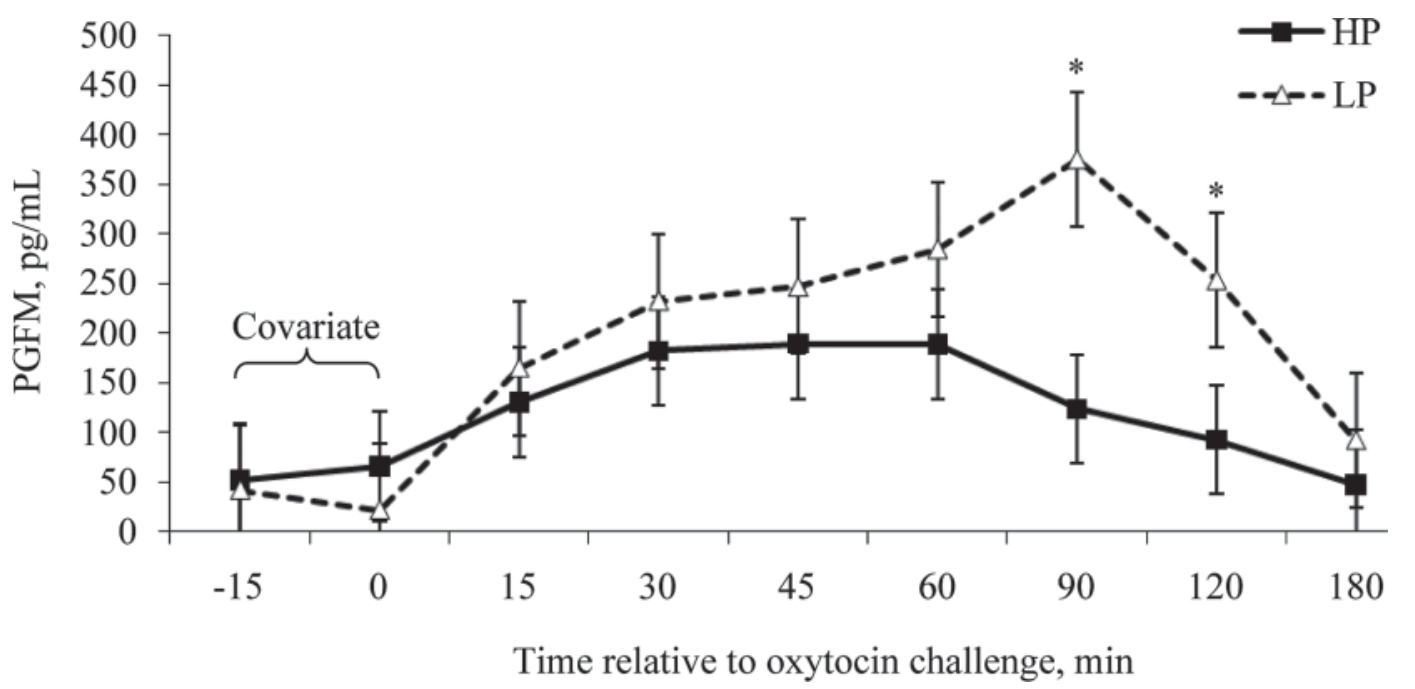

Figure 5. Concentrations of 13, 14-dihydro-15-keto $\mathrm{PGF}_{2 \alpha}$ (PGFM) in plasma of cows in high (HP) and low (LP) progesterone treatments after an oxytocin challenge on study d 16 in experiment 2 . Effect of treatment $(P=0.31)$, time $(P<0.001)$ and interaction between treatment and time $(P=0.01)$. Within each blood collection time, the asterisk $\left(^{*}\right)$ denotes difference between treatments $(P=0.01)$.

induced. The decreased concentrations of progesterone during the synchronization protocol resulted in greater basal LH concentration, faster growth of the dominant follicle, and greater concentrations of circulating estradiol during the proestrus. The numerical increase in double ovulation observed in the present study was, in fact, confirmed in a companion study (Cerri et al., 2011) using a larger number of cows; however, the exact mechanism by which the reduced concentration of progesterone induces co-dominance requires further investigation and is more thoroughly discussed in the companion paper (Cerri et al., 2011). Furthermore, the increased selection of 2 dominant follicles in LP cows assisted to enhance the concentrations of estradiol in plasma (Cerri et al., 2011). Cows in the LP treatment were exposed to greater basal concentrations of $\mathrm{LH}$, which was likely one of the components responsible for faster growth of the dominant follicle and increased concentrations of estradiol, but not progesterone, in the follicular fluid (Fortune et al., 2001). These hormonal changes in the follicular fluid are compatible with results of others that demonstrated increased follicular fluid concentration of estradiol but little change in concentration of progesterone as the follicle develops (Echternkamp et al., 1994). A previous study (ShahamAlbalancy et al., 2000) using a similar experimental design reported greater concentrations of estradiol in the follicular fluid collected on d 15 of the estrous cycle, and on in vitro synthesis of estradiol by the granulosa and theca cells from follicles that developed under low compared with high concentrations of progesterone. In that study, when follicular fluid was collected on d 15 of estrous cycle, follicles were likely in the early stages of the second follicular wave, suggesting that oocytes from these follicles developing under low progesterone are exposed to high concentrations of estradiol for a longer period, which might affect oocyte quality. Collectively, cows with low circulating progesterone have follicles with greater concentrations of estradiol, thereby exposing the oocyte to a longer period of high estradiol, which might be harmful to oocyte maturation (Inskeep, 2004). Nevertheless, a companion study did not detect negative effects on fertilization and early embryo quality (Cerri et al., 2011).

It is not clear whether the concentration of estradiol in the follicular fluid has a direct effect on oocyte maturation. Estradiol is inversely related to IGFBP and thereby affects the free fraction of IGF-1 (Echternkamp et al., 1994; Lucy et al., 1995; Guzeloglu et al., 2001). These changes might have important implications for follicle deviation and development (Rivera and Fortune, 2003; Spicer, 2004). Although several Studies have reported the hormonal profile of the follicular fluid, as well as some of the regulators of estradiol, progesterone, IGF-1, and IGFBP in the ovarian follicle (Lucy et al., 1995; Spicer and Chamberlain, 2000; Guzeloglu et al., 2001; Spicer, 2004), no data have clearly described the effects of circulating concentrations of progesterone on follicular fluid IGF system in dairy cows. Cows with follicular cysts, which typically develop under low systemic concentrations of progesterone, have follicular fluid containing low concentrations of insulin and IGF1 and high activity of IGFBP (Braw-Tal et al., 2009).

Cows in HP had a greater concentration of total IGF-1 and numerically greater free IGF-1 in the follicular fluid, although estradiol concentration was 
less than in LP cows. In fact, negative relationships were observed between follicular fluid concentrations of estradiol and total or free IGF-1 (data not shown). Such differences might explain the changes in follicular dynamics and a possible role of progesterone during development of the ovulatory follicle on fertility of dairy cows (Bisinotto et al., 2010). Pregnancy per AI and pregnancy loss in dairy cows were both better when the ovulatory follicle developed under high concentrations of progesterone (Cunha et al., 2008; Bisinotto et al., 2010). Nevertheless, despite marked changes in the follicle, no differences in fertilization or embryo quality $6 \mathrm{~d}$ after AI were observed between HP and LP cows in a companion study (Cerri et al., 2011). Whether the improvement in fertility previously observed (Cunha et al., 2008; Bisinotto et al., 2010) was caused by changes in the ovulatory follicle or by the effects of the endocrine milieu in the periovulatory period on subsequent uterine function remains to be elucidated.

Treatment did not affect follicle growth and concentrations of progesterone and estradiol in the estrous cycle subsequent to the synchronization protocol in cows with a luteal phase of normal length. The diameter of the CL, however, was larger in LP cows after d 12 of the estrous cycle because the CL of HP cows reached a plateau of diameter sooner than those of LP cows. In a companion study (Cerri et al., 2011), LP cows had a larger CL $6 \mathrm{~d}$ after AI but progesterone concentrations remained unaltered compared with HP cows. One-fourth of the cows in the LP group, however, underwent a short luteal phase, whereas no cows in the HP group suffered from premature CL regression. Progesterone is pivotal in orchestrating the luteolytic cascade by regulating the expression of progesterone receptor, estrogen receptor- $\alpha$, and oxytocin receptor (Silvia et al., 1991). The lack of exposure of the endometrium to progesterone, as in postpartum anovular cows, can promote premature release of $\mathrm{PGF}_{2 \alpha}$, which is thought to be caused by insufficient expression of progesterone receptors and consequent unsynchronized expression of estrogen receptor- $\alpha$ and oxytocin receptor in the endometrium (Garverick et al., 1992; Zollers et al., 1993).

The concentrations of progesterone maintained in LP cows are similar to those observed when the CL is developing, coinciding with the growth of the first-wave dominant follicle. These reduced concentrations of progesterone induced premature upregulation of estrogen receptor- $\alpha$, greater uterine release of $\mathrm{PGF}_{2 \alpha}$, based on PGFM concentrations after the oxytocin challenge, and increased risk of premature luteolysis. All these factors are likely to compromise fertility of dairy cows.

It has been suggested that reduced concentrations of estradiol during proestrus can cause insufficient expres-
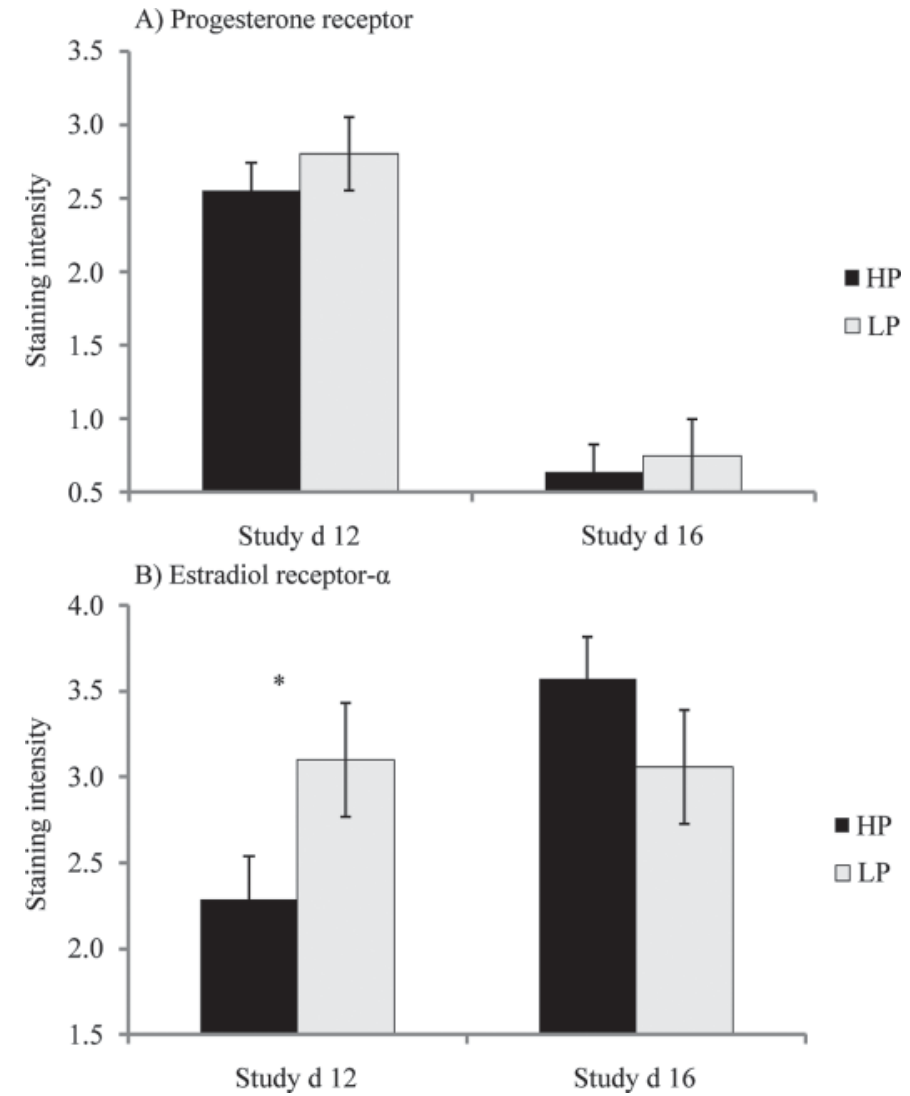

Figure 6. Staining intensity for nuclear progesterone receptor A and B (panel A) and estrogen receptor- $\alpha$ (panel B) proteins of endometrium biopsies of cows in high (HP) and low (LP) progesterone treatments in experiment 2. For progesterone receptor protein abundance, effect of treatment $(P=0.26)$, study day $(P<0.001)$, and interaction between treatment and study day $(P=0.51)$. For estrogen receptor- $\alpha$ abundance, effect of treatment $(P=0.83)$, study day $(P=$ $0.10)$, and interaction between treatment and study day $(P=0.05)$. Within each study day, the asterisk $(*)$ denotes difference between treatments $(P=0.05)$.

sion of progesterone receptors early in the subsequent estrous cycle and consequent premature $\mathrm{PGF}_{2 \alpha}$ synthesis (Mann and Lamming, 2000). However, exposure of the endometrium to both progesterone and estradiol in the preceding cycle is needed for proper timing of the luteolytic cascade in cows (Zollers et al., 1993). In fact, HP cows had concentrations of estradiol that were lower but likely sufficient to prevent premature regression of the CL. The abundance of progesterone receptor in the endometrium decreased dramatically from d 12 to d 16 of the estrous cycle, whereas estrogen receptor- $\alpha$ had a concurrent increase, corroborating previous reports (Spencer and Bazer, 2004). The model based on the sheep (Spencer and Bazer, 2004) suggests that the progesterone receptor is at its peak in mid-estrous cycle but is downregulated after exposure to progesterone, which allows for the expression of estrogen receptor- $\alpha$ before the moment of maternal 

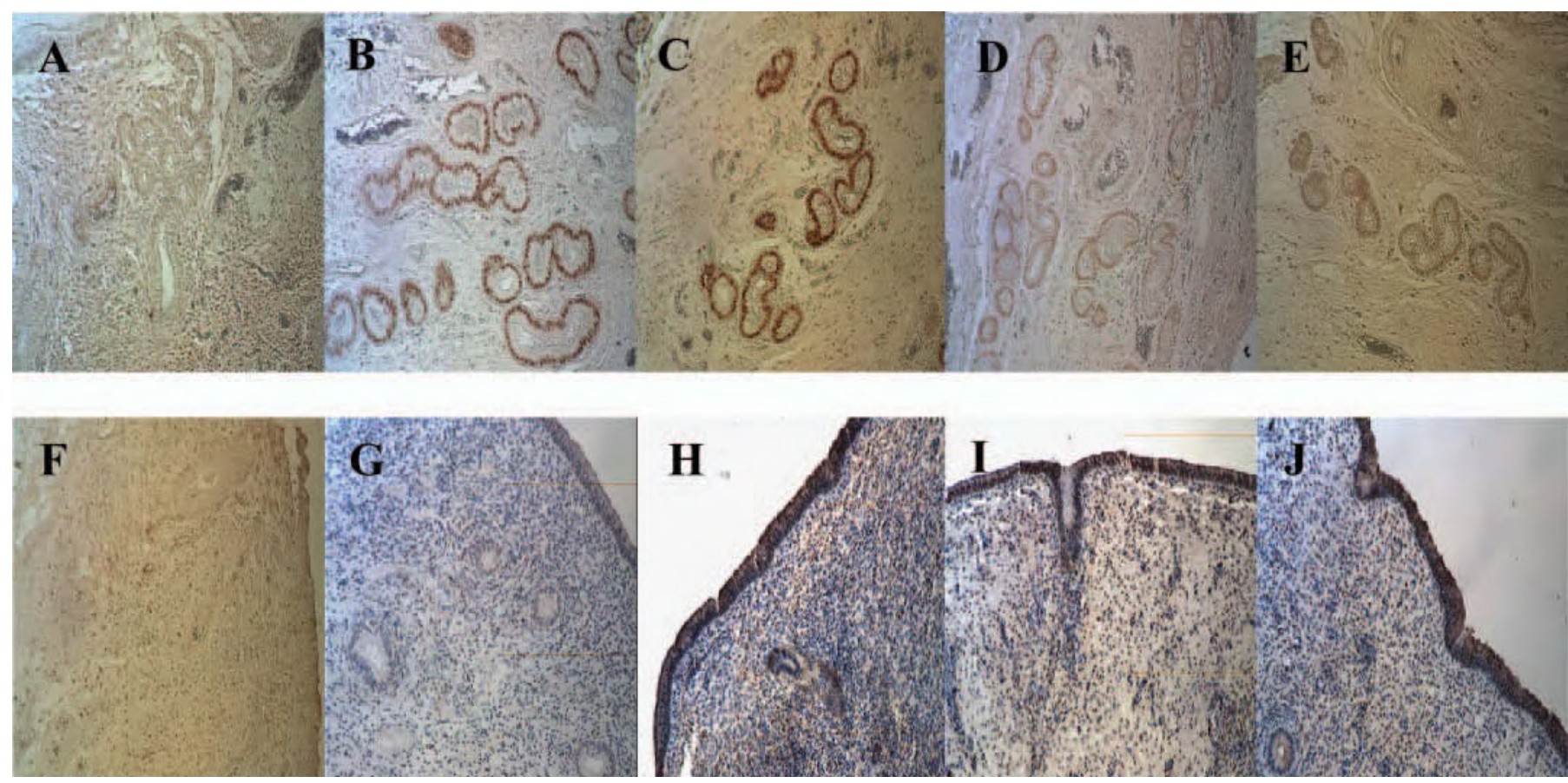

Figure 7. Expression of nuclear progesterone receptor A and B (panels A to E) and estrogen receptor- $\alpha$ (panels F to J) in bovine endometrium from biopsies collected on study d 12 and 16 in experiment 2 . No immunopositive staining was detected when primary antibody was replaced by mouse IgG (A for progesterone receptor; $\mathrm{F}$ for estrogen receptor- $\alpha$ ). The progesterone receptor did not differ on study d $12(P=$ $0.14)$ between high $(\mathrm{B})$ and low progesterone $(\mathrm{C})$ treatments, and on study d $16(P=0.52)$ between high $(\mathrm{D})$ and low progesterone $(\mathrm{E})$ treatments. The progesterone receptor abundance in the endometrium was greater $(P<0.001)$ on study d $12(\mathrm{~B}$ and $\mathrm{C})$ compared with d $16(\mathrm{D}$ and $\mathrm{E})$. Abundance of estrogen receptor- $\alpha$ was less $(P=0.05)$ on study d 12 in the high progesterone $(\mathrm{G})$ compared with the low progesterone $(\mathrm{H})$ treatment, but similar $(P=0.62)$ between high progesterone $(\mathrm{I})$ and low progesterone $(\mathrm{J})$ treatments on study d 16 . Magnification $=20 \times$. Color version available in the online PDF.

recognition of pregnancy. In cows, Okumu et al. (2010) found that progesterone receptor mRNA and protein expression decreased and estrogen receptor-2 mRNA increased as the estrous cycle progressed, showing some similarities to the current study. In addition, the same study demonstrated that concentration of progesterone in blood early in the estrous cycle could change its receptor protein and estrogen receptor- 2 mRNA expression in the endometrium during the mid-luteal phase. Although progesterone concentrations were altered after ovulation and not before, as in the current study, it collectively demonstrates that circulating progesterone has a remarkable effect on the expression of steroid receptors in the endometrium that might have significant effects on embryo survival. Furthermore, Forde et al. (2011) observed changes in endometrial gene expression that was associated with a reduced capacity of the uterus to support conceptus elongation when lower concentrations of progesterone were observed in the first few days after estrus. It is reasonable, therefore, to believe that reduced concentrations of progesterone before ovulation can also modify endometrial gene expression beyond just steroid receptors to a variety of other genes that might be essential to support early embryonic survival.
Compared with HP counterparts, cows in the LP treatment had a greater abundance of estrogen receptor- $\alpha$ on d 12 but not on d 16 of the estrous cycle. These results suggest that cows exposed to lower concentrations of progesterone might have compromised fertility in part because of an inability to block the luteolytic signals and maintain the embryo. This asynchrony might overwhelm the ability of the conceptus to block the $\mathrm{PGF}_{2 \alpha}$ synthesis cascade, which partly explains the increased risk of early embryonic losses observed in anovular cows that develop the ovulatory follicle under low concentrations of progesterone. In addition, increased $\mathrm{PGF}_{2 \alpha}$ synthesis may have a direct toxic effect to the early embryo (Inskeep, 2004), which could affect further development when the CL is preserved.

\section{CONCLUSIONS}

Decreased concentrations of progesterone during recruitment and development of the ovulatory follicle caused faster growth of the dominant follicle and increased concentrations of estradiol and LH. The concentration of estradiol in the antral fluid of the dominant follicle was increased in LP cows, although total IGF-1 
was less than in HP cows. The systemic and localized hormonal changes might explain the reduced fertility of cows that develop the ovulatory follicle under low concentrations of progesterone. Exposing cows to low concentrations of progesterone during development of the ovulatory follicle hastened luteolysis by influencing estrogen receptor- $\alpha$ and $\mathrm{PGF}_{2 \alpha}$ release by the uterus. Collectively, these results suggest that reduction in fertility of dairy cows exposed to low progesterone during development of the ovulatory follicle might be mediated by changes in follicular fluid composition, uterine function, and CL lifespan.

\section{ACKNOWLEDGMENTS}

This research was supported by grants from the USDA Formula Funds and Select Sires Inc. (Plain City, OH). The authors thank John Adaska from the California Animal Health Food Safety Laboratory System (Tulare, CA) and F. Silvestre from the Department of Animal Sciences at the University of Florida (Gainesville) for their help with the endometrial biopsy samples and PGFM assay. We acknowledge A. F. Parlow at the National Hormone and Pituitary Program (Torrance, CA) for providing the ovine LH and antisera. Our gratitude is also extended to Oscar Rodriguez and the staff of the Corcoran State Prison dairy farm (Corcoran, CA).

\section{REFERENCES}

Ahmad, N., F. N. Schrick, R. L. Butcher, and E. K. Inskeep. 1995. Effect of persistent follicles on early embryonic losses in beef cows. Biol. Reprod. 52:1129-1135.

Beal, W. E., R. A. Milvae, and W. Hansel. 1980. Oestrous cycle length and plasma progesterone concentrations following administration of prostaglandin $\mathrm{F}_{2 \alpha}$ early in the bovine oestrous cycle. J. Reprod. Fertil. 59:393-396.

Beltman, M. E., J. F. Roche, P. Lonergan, N. Forde, and M. A. Crowe, 2009. Evaluation of methods to induce low progesterone during the early luteal phase in cattle. Theriogenology 72:986-992.

Bisinotto, R. S., R. C. Chebel, and J. E. P. Santos. 2010. Follicular wave of the ovulatory follicle and not cyclic status influences fertility of dairy cows. J. Dairy Sci. 93:3578-3587.

Braw-Tal, R., S. Pen, and Z. Roth. 2009. Ovarian cysts in high-yielding dairy cows. Theriogenology 72:690-698.

Cerri, R. L. A., R. C. Chebel, F. Rivera, C. D. Narciso, R. A. Oliveira, and J. E. P. Santos. 2011. Concentration of progesterone during the development of the ovulatory follicle: I. Ovarian and embryonic responses. J. Dairy Sci. 94:3342-3351. doi:10.3168/jds.20103734

Cerri, R. L. A., H. M. Rutigliano, R. C. Chebel, and J. E. P. Santos 2009. Period of dominance of the ovulatory follicle influences embryo quality in lactating dairy cows. Reproduction 137:813-823.

Cerri, R. L. A., J. E. P. Santos, S. O. Juchem, K. N. Galvão, and R. C. Chebel. 2004. Timed artificial insemination with estradiol cypionate or insemination at estrus in high-producing dairy cows. J. Dairy Sci. 87:3704-3715.

Cunha, A. P., J. N. Guenther, M. J. Maroney, J. O. Giordano, A. B Nascimento, S. Bas, H. Ayres, and M. C. Wiltbank. 2008. Effects of high vs. low progesterone concentrations during Ovsynch on double ovulation rate and pregnancies per AI in high producing dairy cows. J. Dairy Sci. 91(Suppl. 1):246. (Abstr.)

Echternkamp, S. E., H. J. Howard, A. J. Roberts, J. Grizzle, and T. Wise. 1994. Relationships among concentrations of steroids, insulin-like growth factor-1, and insulin-like growth factor binding proteins in ovarian follicular fluid of beef cattle. Biol. Reprod. 51:971-981.

Ferguson, J. D., D. T. Galligan, and N. Thomsen. 1994. Principal descriptors of body condition score in Holstein cows. J. Dairy Sci. 77:2695-2703.

Forde, N., M. E. Beltman, G. B. Duffy, P. Duffy, J. P. Mehta, P. Ó'Gaora, J. F. Roche, P. Lonergan, and M. A. Crowe. 2011. Changes in the endometrial transcriptome during the bovine estrous cycle: Effect of low circulating progesterone and consequences for conceptus elongation. Biol. Reprod. 84:266-278. doi:10.1095/ biolreprod.110.085910.

Fortune, J. E., G. M. Rivera, A. C. O. Evans, and A. M. Turzillo. 2001. Diferentiation of dominant versus subordinate follicles in cattle. Biol. Reprod. 65:648-654.

Fortune, J. E., G. M. Rivera, and M. Y. Yang. 2004. Follicular development: The role of the follicular microenvironment in selection of the dominant follicle. Anim. Reprod. Sci. 82-83:109-126.

Garverick, H. A., W. G. Zollers, and M. F. Smith. 1992. Mechanisms associated with corpus luteum lifespan in animals having normal or subnormal luteal function. Anim. Reprod. Sci. 28:111-124.

Guilbault, L. A., W. W. Thatcher, M. Drost, and S. M. Hopkins. 1984. Source of $\mathrm{F}$ series prostaglandins during the early postpartum period in cattle. Biol. Reprod. 31:879-887.

Guzeloglu, A., J. D. Ambrose, T. Kassa, T. Diaz, M. J. Thatcher, and W. W. Thatcher. 2001. Long-term follicular dynamics and biochemical characteristics of dominant follicles in dairy cows subjected to acute heat stress. Anim. Reprod. Sci. 66:15-34.

Inskeep, E. K. 2004. Preovulatory, postovulatory, and postmaternal recognition effects of concentrations of progesterone on embryonic survival in the cow. J. Anim. Sci. 82(E. Suppl.):E24-E39.

Inskeep, E. K., and R. A. Dailey. 2005. Embryonic death in cattle. Vet. Clin. North Am. Food Anim. Pract. 21:437-461.

Kirby, C. J., M. F. Smith, D. H. Keisler, and M. C. Lucy. 1997. Follicular function in lactating dairy cows treated with sustained-release bovine somatotropin. J. Dairy Sci. 80:273-285.

Lucy, M. C., W. W. Thatcher, R. J. Colier, F. A. Simmen, Y. Ko, J. D. Savio, and L. Badinga. 1995. Effects of somatotropin on the conceptus, uterus, and ovary during maternal recognition of pregnancy in cattle. Domest. Anim. Endocrinol. 12:73-82.

Mann, G. E., and G. E. Lamming. 2000. The role of sub-optimal preovulatory oestradiol secretion in the aetiology of premature luteolysis during the short oestrous cycle in the cow. Anim. Reprod. Sci. $64: 171-180$

Mattos, R., C. R. Staples, J. Williams, A. Amorocho, M. A. McGuire, and W. W. Thatcher. 2002. Uterine, ovarian, and production responses of lactating dairy cows to increasing dietary concentrations of menhaden fish meal. J. Dairy Sci. 85:755-764.

McVey, W. R., Jr., and G. L. Williams. 1991. Mechanical masking of neurosensory pathways at the calf-teat interface: Endocrine, reproductive and lactational features on the suckled anestrous cow. Theriogenology 35:931-941.

National Research Council. 2001. Nutrient Requirements of Dairy Cattle. 7th rev. ed. Natl. Acad. Press, Washington, DC.

Okumu, L. A., N. Forde, A. G. Fahey, E. Fitzpatrick, J. F. Roche, M. A. Crowe, and P. Lonergan. 2010. The effect of elevated progesterone and pregnancy status on mRNA expression and localisation of progesterone and oestrogen receptors in the bovine uterus. Reproduction 140:143-153.

Revah, I., and W. R. Butler. 1996. Prolonged dominance of follicles and reduced viability of bovine oocytes. J. Reprod. Fertil. 106:39-47.

Rivera, G. M., and J. E. Fortune. 2003. Selection of the dominant follicle and insulin-like growth factor (IGF)-binding proteins: Evidence that pregnancy-associated plasma protein A contributes to proteolysis of IGF-binding protein 5 in bovine follicular fluid. Endocrinology 144:437-446. 
Sangsritavong, S., D. K. Combs, R. Sartori, L. E. Armentano, and M. C. Wiltbank. 2002. High feed intake increases liver blood flow and metabolism of progesterone and estradiol- $17 \beta$ in dairy cattle. J. Dairy Sci. 85:2831-2842.

Sartori, R., J. M. Haughian, R. D. Shaver, G. J. M. Rosa, and M. C. Wiltbank. 2004. Comparison of ovarian functions and circulating steroids in estrous cycles of Holstein heifers and lactation cows. J. Dairy Sci. 87:905-920.

Savio, J. D., W. W. Thatcher, L. Badinga, R. L. de la Sota, and D. Wolfenson. 1993. Regulation of dominant follicle turnover during the oestrous cycle in cows . J. Reprod. Fertil. 97:197-203.

Shaham-Albalancy, A., Y. Folmal, M. Kaim, M. Rosenberg, and D. Wolfenson. 2001. Delayed effect of low progesterone concentration on bovine uterine PGF2a secretion in the subsequent oestrous cycle. Reproduction 122:643-648.

Shaham-Albalancy, A., M. Rosenberg, Y. Folman, Y. Graber, R. Meidan, and D. Wolfenson. 2000. Two methods of inducing low plasma progesterone concentrations have different effects on dominant follicles in cows. J. Dairy Sci. 83:2771-2778.

Silvia, W. J., G. S. Lewis, J. A. McCracken, W. W. Thatcher, and L. Wilson Jr. 1991. Hormonal regulation of uterine secretion of prostaglandin $\mathrm{F}_{2 \alpha}$ during luteolysis in ruminants. Biol. Reprod. 45:655-663.
Spencer, T. E., and F. W. Bazer. 2004. Conceptus signals for establishment and maintenance of pregnancy. Reprod. Biol. Endocrinol. 2:49.

Spicer, L. J. 2004. Proteolytic degradation of insulin-like growth factor binding proteins by ovarian follicles: A control mechanism for selection of dominant follicles. Biol. Reprod. 70:1223-1230.

Spicer, L. J., and C. S. Chamberlain. 2000. Estradiol and luteinizing hormone regulation of insulin-like growth factor binding protein production by bovine granulose and thecal cells. J. Anim. Sci. 78:2919-2926.

Vasconcelos, J. L. M., S. Sangsritavong, S. J. Tsai, and M. C. Wiltbank. 2003. Acute reduction in serum progesterone concentrations after feed intake in dairy cows. Theriogenology 60:795-807.

Wiltbank, M. C., H. Lopez, R. Sartori, S. Sangsritavong, and A. Gumen. 2006. Changes in reproductive physiology of lactating dairy cows due to elevated steroid metabolism. Theriogenology 65:1729.

Zollers, W. G., Jr., H. A. Garverick, M. F. Smith, R. J. Moffatt, B. E. Salfen, and R. S. Youngquist. 1993. Concentrations of progesterone and oxytocin receptors in endometrium of postpartum cows expected to have a short or normal oestrus cycle. J. Reprod. Fertil. 97:329-337. 